Agro-Science Journal of Tropical Agriculture, Food, Environment and Extension Volume 16 Number 1 (January 2017) pp. $42-47$

ISSN 1119-7455

\title{
ASSESSMENT OF PESTS CONTROL METHODS AND ITS PERCEIVED EFFECT ON AGRICULTURAL PRODUCTION AMONG FARMERS IN KWARA STATE, NIGERIA
}

\author{
${ }^{1,2}$ Alalade, O.A., ${ }^{2}$ Matanmi, B.M., ${ }^{3 *}$ Olaoye, I.J., ${ }^{2}$ Adegoke, B.J., and ${ }^{4}$ Olaitan, T.R.
}

${ }^{1}$ Department of Agricultural Development Management, Agricultural and Rural Management Training Institute (ARMTI), Ilorin, Nigeria

${ }^{2}$ Department of Agricultural Extension \& Rural Development, University of Ilorin, Ilorin, Nigeria ${ }^{3}$ Department of Agricultural Economics \& Farm Management, University of Ilorin, Ilorin, Nigeria

${ }^{4}$ Nigeria Stored Product Research Institute, Ilorin, Nigeria

*Corresponding author's email: olaoyeibukunjames@yahoo.com

\begin{abstract}
The study examined the usage of chemical and biological pests control methods among the farmers in Kwara State, Nigeria. A three-stage random sampling technique was used to select 120 respondents. A well structure questionnaire was used to collect the data for the study. Descriptive statistics and partial correlation were used in analyzing the data. The study revealed that all the farmers were aware of the cultural pest control method, while 73.3 and $17.5 \%$ were aware of chemical and biological methods, respectively. Also, it revealed that $44.2 \%$ of the respondents use the chemical method of pest control, $7.5 \%$ use the biological method while all use the cultural method of pest control. Television remains the major means of accessing information by the respondents. The perceived effect of pest control methods on shelf life, marketability, productivity and profitability of the agricultural product ranked $1^{\text {st }}, 2^{\text {nd }}$, $3^{\text {rd }}$ and $4^{\text {th }}$ most ranked effect with weighted mean score of 4.26, 3.44, 3.39 and 3.20, respectively while perceived effect on pollution, loss of soil fertility and ecosystem imbalance were ranked $7^{\text {th }}, 8^{\text {th }}$ and $9^{\text {th }}$, respectively. There is a significant $(p<0.05)$ relationship between age, educational level, household size, farm size and the perceived effect of both chemical and biological pest control methods. The study therefore concludes that majority of the respondents have adopted the use of chemical method over biological method of pest control and that farmers have been using integrated pest control management. The pest control methods used were believed to have a positive effect on shelf life, marketability and productivity of their agricultural products. The study recommends the need to sensitize famers on the use and benefits of biological pest control methods as well as the adverse effect that might result from the excessive usage of chemical pest control method given the growing rate of its adoption.
\end{abstract}

Key words: cultural, chemical, biological, integrated management, shelf life, marketability

\section{INTRODUCTION}

Pests are known to have negative impact on crop production as well as on human health (Tinyami et al., 2014). The word "pest" describes an organism that damages crops, injures or irritates livestock or man. Agricultural pests includes animals, insects, fungi, and bacteria that lead to a loss of crops or reduction in crop yield relative to potential yield that would be possible in a world without pests (Sexton et al., 2007). Pest attack in agriculture is usually observed both on the field and during period of storage of agricultural crops most especially in cereal production. Shamser et al. (1976) reported that the attack by various insect pests causes damage to plant foliate, stems, buds, flowers, fruits and seeds resulting in substantial crop losses of marketable yield. However, controlling pests is important in the agricultural industry. Annually, it is estimated to cost farmers worldwide about 10 billion dollars to control pests
(Van Lenteren, 2005). If this loss can be averted using pesticides, food can be made available for the world population thereby reducing global hunger directly, and positively affecting the poverty line which addresses one of the millennium development goals (Aktar et al., 2009). However, pesticides use in crop production has been reported to be a major contribution to environmental pollution (Parveen and Nakagoshi, 2001).

Historically, in the 1930's, DDT (Dichlorodiphenyltrichloroethane) was widely acclaimed as a pesticide, contributing significantly to increase in the turnover of agricultural products especially food crops, but it was later discredited as a result of its tetratogenic effects in the 1960s (Bretveld et al., 2006). In later times, more effective pesticides have been introduced into agriculture with lesser adverse effects. Also, the biological control method which involves the use

Please cite as: Alalade, O.A., Matanmi, B.M., Olaoye, I.J., Adegoke, B.J., and Olaitan, T.R. (2017). Assessment of pests control methods and its perceived effect on agricultural production among farmers in Kwara State, Nigeria. Agro-Science, 16 (1), $42-47$. DOI: https://dx.doi.org/10.4314/as.v16i1.8 
of animals that serves as predators to control pests, promises to be a more environmental friendly control method. According to Bueno (2011) who reported that biological control is the management and regular release of beneficial anthropods or microorganisms in crops in order to boost naturally occurring levels of these natural enemies. Worldwide, it is estimated to be applied to 0.16 million $\mathrm{km}^{2}$ commercially. The application of biological control by conversion is on the increase (Bueno, 2011). Predators and parasites of the pests can also be used to control pests. Using biological control method does not eradicate the parasite but controls it, so it is manageable and natural. Ideally, the parasite and pests should be in balance with each other, where the pest has little effect.

In Africa, majority of farmers depend on indigenous pest management approaches to manage pest problem (Abate et al., 2000). However, in recent times many of the small-scale farmers have turned to pesticide use which they recognize will reduce crop loss and improve crop production (Damalas and Eleftherohorinos, 2011). The pesticide related issues have been increasingly and extensively highlighted in the media and have attracted sharp focus among industrial and developing countries (Selvarajah and Thiruchelvam, 2007). A rough estimate shows that about one third of the world's agricultural production is lost every year due to pest despite pesticides use which totaled more than 2 million tons (FAO, 2005). Farmers consider pesticide use to be labor saving, as well as an effective and efficient tool which controls pests.

However, the extent of damage caused by pest on agricultural products is high and the challenge with the excessive use of pesticides on environment, food poisoning and food insecurity is of great concern. Although, insects and other species that damage crops or that transmit diseases to people or animals are therefore pest that needs to be controlled as far as possible. Thus, the long term consequences of the use of these chemicals went largely unconsidered in view of its short term benefits. The impact of chemical pesticides were initially positive, and people benefited enormously from it, but over time, it became clear that some of these pesticides had serious negative impacts on human health and the environment at large (SPIPM, 2006). The study becomes necessary as pest control remains one of the most important farm operations in crop production cycle. Specifically, the objectives of the study were; to determine the level of use of pest control methods in the study area; to ascertain the perceived effect of pest control methods on agricultural production and performance and to identify the constraints encountered by farmers in the use of both chemical and biological methods of pest control in the study area and to test the hypothesis that:
Ho: there is no significant relationship between socio-economic characteristics of the respondents and the level of the use of the chemical and biological pest control methods.

\section{MATERIALS AND METHODS}

The study was carried out in selected local government areas (Ilorin East, Ifelodun, Irepodun and Asa) in Kwara State. Kwara is situated in North-Central Nigeria. The primary ethnic group of the State is Yoruba, with significant Nupe, Baruba Hausa minorities. Kwara State lies on latitude $7^{0}$ $15^{\prime} \mathrm{N}$ and longitude $6^{\circ} 18^{\prime} \mathrm{E}$ and covers a land area of about $32500 \mathrm{~km}^{2}$. The state shares common boundaries with Oyo, Ondo, Osun, Niger and Kogi States and has an international border with the Republic of Benin (Kwara State Ministry of Information, 2011). Kwara State has about 260,528 farm families (KWADP, 2006) and about 36,820 hectares of farmland (FOS, 1995).

A three-stage random sampling technique was used for the study. The first stage involves a random selection of four local government areas in Kwara State while the second stage involves a random selection of three villages in each of the selected local government areas and the third stage involves the random selection of 10 respondents from each of the villages. A total of 120 respondents were selected for the study. Primary data were used for this study and were collected through the use of a well-structured questionnaire. Data were analyzed using frequencies, mean, percentages, ranks, while Pearson correlation was used to examine the differences between the test variables and the generated hypothesis.

The perceived effect of the use of chemical and biological pest control methods and challenges faced using the pest control methods were measured using a 5-point Likert scale and analyzed using the weighted mean score.

\section{Pearson Moment Correlation}

Pearson moment correlation coefficient was used to measure the relationship between socio-economic characteristics of the respondents and the perceived effect of chemical and biological pest control methods given the tested hypothesis. The correlation coefficient was given as:

$$
\mathrm{r}=\frac{N \sum X Y-\sum X \sum Y}{\sqrt{N \sum X^{2}-\left(\sum X\right)^{2}\left[N \sum Y^{2}-\left(\sum Y\right)^{2}\right]}}
$$

where $r$ is correlation coefficient, $X$ is socioeconomic characteristics, and $Y$ is perceived effect of chemical method and biological method of pest control (mean score). 


\section{RESULTS AND DISCUSSION}

Socio-Economic Characteristics of Respondents

Table 1 shows that most $(87.5 \%)$ of the farmers were male, the age bracket of 26-35 years had the highest percentage of $25 \%$, while the mean age of the respondents was 47 years, showing that middleaged generations were more active in rural farming than older generations, who are gradually phasing out of farming system. Also, most (90.8\%) of the respondents were married. This is in consonance with the report of Peng (2003) that rural farmers place a lot more emphasis on and respect the institute of marriage as opposed to urban farmers. Table 1 also revealed that $26 \%$ of the respondents had no formal education while 18.3 and $19.2 \%$ of the respondents had secondary and tertiary education, respectively. The percentage of farmers with tertiary education is much more than $3.34 \%$ reported by Agbaje et al. (2013) which made a reasonable number of them to be familiar with both biological and chemical pest control method. Most $(82.5 \%)$ of the respondents were Muslims while 16.7 and $0.8 \%$ of the respondents were Christians and traditional worshippers, respectively. This was contrary to an earlier notion that majority of rural farmers were traditional worshippers in the report of Idehen and Oshodin (2007).

\section{Awareness and Types of Pest Control Methods Used among Farmers}

Table 2 shows that all the farmers were aware of the cultural pest control method while $73.3 \%$ were aware of chemical method and $17.5 \%$ were aware of biological method. This supported the study of Selvarajah and Thiruchelvam (2007) which showed that farmers possessed moderate level of knowledge in most of the aspects of pesticide use. Table 2 also reveals that greater proportion $(44.2 \%)$ of the farmers used chemical method of pest control, while $7.5 \%$ used biological method. About $8.3 \%$ used both methods while $40 \%$ of the farmers solely used cultural methods of pest control such as sun drying, timely harvesting and timely weed control. This means that most of the farmers have used at least a method of pest control. This result indicates that most of the farmers were already aware of the information as regards chemical control methods. More so, Table 2 shows that $52.5 \%$ of the farmers have used organophosphates to control pests, while 31.7 and $19.2 \%$ have used carbamates and pyrethroids respectively. This is probably because DD Force which is a very popular brand of organophosphates might have been widely promoted and this stimulates its adoption by major rural farmers. This result is actually in consonance with the work of Tinyami et al. (2014) who reported that most farmers use pesticides from the following compounds; Pyrethoid, rganophosphorus, Organochlorine, Carbamate, Benzimidazole, Glycine derivative and Denitroaline chemical groups.
Table 1: Distribution of respondents according to socioeconomic characteristics

\begin{tabular}{|c|c|c|}
\hline Variable & Frequency & Percentages \\
\hline \multicolumn{3}{|l|}{ Gender } \\
\hline Male & 105 & 87.5 \\
\hline Female & 15 & 12.5 \\
\hline \multicolumn{3}{|l|}{ Age } \\
\hline$\leq 25$ & 10 & 8.3 \\
\hline $26-35$ & 30 & 25.0 \\
\hline $36-45$ & 26 & 21.7 \\
\hline $46-55$ & 17 & 14.2 \\
\hline $56-65$ & 16 & 13.3 \\
\hline $66-75$ & 12 & 10.0 \\
\hline$\geq 76$ & 9 & 7.5 \\
\hline \multicolumn{3}{|l|}{ Marital status } \\
\hline Single & 11 & 9.2 \\
\hline Married & 109 & 90.8 \\
\hline \multicolumn{3}{|l|}{ Educational Level } \\
\hline No formal Education & 32 & 26.7 \\
\hline Adult Education & 2 & 1.7 \\
\hline Quranic Education & 21 & 17.5 \\
\hline Primary Education & 20 & 16.5 \\
\hline Secondary Education & 22 & 18.3 \\
\hline Tertiary Education & 23 & 19.2 \\
\hline \multicolumn{3}{|l|}{ Religion } \\
\hline Christianity & 20 & 16.7 \\
\hline Islam & 99 & 82.5 \\
\hline Traditional & 1 & 0.8 \\
\hline \multicolumn{3}{|l|}{ Household Size } \\
\hline$\leq 5$ & 29 & 24.2 \\
\hline $6-10$ & 56 & 46.7 \\
\hline $11-15$ & 22 & 18.3 \\
\hline $16-20$ & 11 & 9.2 \\
\hline$\geq 21$ & 2 & 1.7 \\
\hline Total & 120 & 100.0 \\
\hline
\end{tabular}

Source: Field Survey 2016

Table 2:Awareness and Usage of different Types of Pest Control Methods

\begin{tabular}{lcc}
\hline Method & Yes & No \\
\hline Farmers Awareness & & \\
Chemical & $88(73.3 \%)$ & $32(26.7 \%)$ \\
Biological & $21(17.5 \%)$ & $99(82.5 \%)$ \\
Cultural & $120(100.0 \%)$ & $0(0.0 \%)$ \\
Used Method & & \\
Cultural & $120(100.0)$ & $0(0.0 \%)$ \\
Chemical & $53(44.2 \%)$ & $67(55.8 \%)$ \\
Biological & $9(7.5 \%)$ & $111(92.5 \%)$ \\
Both Methods & $9(7.5 \%)$ & $111(92.5 \%)$ \\
Cultural Method Used & & \\
Timely harvest & $120(100.0 \%)$ & $0(0.0 \%)$ \\
Time weeding & $120(100.0 \%)$ & $0(0.0 \%)$ \\
Sun drying & $82(68.3 \%)$ & $38(31.7 \%)$ \\
Chemical Method Used & & \\
Organophosphate & $53(44.2 \%)$ & $67(55.8 \%)$ \\
Carbamate & $38(31.7 \%)$ & $82(68.3 \%)$ \\
Pyrethroid & $23(19.2 \%)$ & $97(80.8 \%)$ \\
Biological Methods Used & & \\
Predators & $0(0.0 \%)$ & $120(100.0 \%)$ \\
Parasites & $0(0.0 \%)$ & $120(100.0 \%)$ \\
Resistant Varieties & $11(9.2 \%)$ & $109(90.8 \%)$ \\
Plant Materials/residues & $7(5.8)$ & $113(94.12)$ \\
\hline Source: Field Survey 2016 & &
\end{tabular}

Source: Field Survey 2016

Also shown in Table 2 is the fact that all the farmers used timely harvest and timely weed control as cultural pest control method while $68.3 \%$ of the farmers used sun drying. However this was in contrast to the report of Oladele et al. (2014) that the most prevalent cultural method of pest control was crop rotation. On the basis of biological pest control methods, the use of resistant varieties $(9.2 \%)$ and 
use of plant material/residue $(5.8 \%)$ have an unprecedented lower usage but relatively higher percentage of usage when compared to other biological pest control methods such as use of predators $(0 \%)$ and use of parasites $(0 \%)$. This might be partly due to the ease at which it can be carried out without intricate technicalities unlike other biological control methods which require expertise and possibly training to prevent undesirable sideeffects like crop destruction as reported in the works of Bale et al. (2008) and Mills and Daane (2005). Thus, this was in concordance with the report of Tinyami et al. (2014) that few farmers always continue to use wood ash and animal droppings for pest control by sprinkling the mixture over their vegetables when they cannot afford to buy pesticides.

Table 3 shows the means of accessing information on current agricultural practices among farmers in Kwara State. It reveals that television serves as a major means of accessing information having a weighted mean 2.53 on a 3 -point Likert scale. The second means of accessing information among the respondents was through family/friends and extension workers having an equal weighted mean score of 2.08. Moreover, accessing information through agro-input dealers, radio and newspapers were ranked $4^{\text {th }}, 5^{\text {th }}$ and $6^{\text {th }}$ with weighted mean score of $1.97,1.89,1.21$, respectively on a 3-point Likert scale. However, this indicates the importance of television, farmers' families/friends and extension agent as the means of extending information generally to farmers. It then suggests that these channels will be effective ways government agencies can reach out to the farmers for effective communication of new and advance agricultural practices as stated in the work of Oladele (2006).

\section{Perceived Effects of the use of both Biological and Chemical Pest Control Methods}

Table 4 shows the perceived effects of the use of both biological and chemical pest control methods. A 5-point likert scale; strongly agree, agree, indifference, disagree and strongly disagree was used to capture the farmers perception on the use of pest control method. The computed weighted mean score was used to rank the identified effect of the pest control methods. The result showed that the effect of pest control methods to increase shelf life of the agricultural product is the $1^{\text {st }}$ most ranked effect with weighted mean score of 4.26. The perceived effect of chemical and biological pest control methods on marketability, productivity (yield) and profitability with the weighted mean scores of $3.44,3.39$, and 3.20 were ranked $2^{\text {nd }}, 3^{\text {rd }}$ and $4^{\text {th }}$, respectively. However, the effect on flowering rate on agricultural plants, food poisoning, environmental pollution, loss of soil fertility and ecosystem imbalance have the weighted mean score of $3.08,2.38,1.73,1.60$, and 1.31 , respectively. Therefore, the farmers perceived the use of both biological and chemical control methods has the least effect of causing ecosystem imbalance and thus ranked $9^{\text {th }}$. Thus, this result is in consonance with the work of Abunyewah et al. (2015) which stated that adequate pest control method enhances majorly the qualities of agricultural products which might enhance its marketability and shelf life. However, Oladele et al. (2014) and Tinyamin et al. (2014) reported that the indiscriminate use of chemical pesticides to achieve higher yields could lead to disruption of natural ecosystems and increase the risk of contamination of the farm environment, pesticide residues in fresh produce and health risk to consumers. Also, most of the pesticides applied are potent toxins and their intensive use poses potential hazards to humans, livestock and the environment (Chambers et al., 2001; Ngowi et al., 2007).

Constraints faced by Farmers in the use of Chemical and Biological Method of Pest Control Table 5 shows the severity of the constraints experienced by farmers in the use of various methods of pest control. A 5-point Likert scale (very severe, severe, moderately severe, less severe and not severe) was used to measure the severity of the constraints using chemical and biological pest control method having the rate of 5, 4, 3, 2, and 1, respectively. High cost of chemical and biological pest control methods was found having a weighted mean score of 3.53 and hence could be considered to be a severe constraint faced by the respondents in the study area. Other constraints such as, long distance to the agro dealer outlet, health challenges implication, inadequate access, adverse effect on soil fertility and adverse effect on yield have the weighted mean scores of 2.28, 2.27, 2.22, 2.17, 2.00 and 1.61, respectively. Thus, these other constraints could be considered to be less severe in the study area. This result was similar to the report of Charles (2014) that smallholder farmers were faced with major constraints of expensive input, lack of technical knowledge and limited access of agricultural inputs. Also Gerald et al. (1995) reported high cost of pesticides on large farm size.

Hypothesis Testing (Pearson Moment Correlation) $\mathrm{H}_{1}$ : There is a significant relationship between socio-economic characteristics of the respondents and the perceived effect of the use of chemical and biological pest control methods. Table 6 shows the Pearson moment correlation coefficients. There is a significant $(\mathrm{p}<0.05)$ relationship between perceived effect of the use of chemical and biological pest control methods with age $(-0.27)$, household size $(-0.21)$, and years of farming $(-0.23)$ of the respondents. The negative coefficient of correlation shows that as the age of the respondents' increases, the perceived effect of chemical and biological pest control methods decreases. This implies that as age 
Table 3: Preferred source of information on pests control

\begin{tabular}{lrrrrc} 
Information Source & $\begin{array}{r}\text { Very Preferred } \\
\text { Frequency (\%) }\end{array}$ & $\begin{array}{c}\text { Preferred } \\
\text { Frequency (\%) }\end{array}$ & $\begin{array}{c}\text { Not Preferred } \\
\text { Frequency (\%) }\end{array}$ & Mean & Rank \\
\hline Family \& friends & $50(41.7 \%)$ & $29(24.2 \%)$ & $41(34.2 \%)$ & 2.08 & $2^{\text {nd }}$ \\
Radio & $35(29.2 \%)$ & $37(30.8 \%)$ & $48(40.0 \%)$ & 1.89 & $5^{\text {th }}$ \\
Television & $86(71.7 \%)$ & $11(9.2 \%)$ & $23(19.2 \%)$ & 2.53 & $1^{\text {st }}$ \\
Agro-input dealers & $42(35.0 \%)$ & $32(26.7 \%)$ & $46(38.3 \%)$ & 1.97 & $4^{\text {th }}$ \\
Extension workers & $50(41.6 \%)$ & $29(24.2 \%)$ & $41(34.2 \%)$ & 2.08 & $2^{\text {nd }}$ \\
Newspapers & $11(9.2 \%)$ & $3(2.5 \%)$ & $106(88.3 \%)$ & 1.21 & $6^{\text {th }}$ \\
\hline
\end{tabular}

Source: Field Survey 2016

Table 4: Perceived effect of pest control on agricultural production and performance

\begin{tabular}{lccccccc}
\hline Perceived effect & SA & A & I & D & SD & Mean & Rank \\
\hline Productivity (Yield) & $30(25.0)$ & $41(34.2)$ & $7(5.8)$ & $30(25.0)$ & $12(10.00)$ & 3.39 & $3^{\text {rd }}$ \\
Loss of soil fertility & $2(1.7)$ & $3(2.5)$ & $0(0.0)$ & $55(45.8)$ & $60(50.0)$ & 1.60 & $8^{\text {th }}$ \\
Marketability & $43(35.8)$ & $23(19.2)$ & $9(7.5)$ & $34(28.3)$ & $11(9.2)$ & 3.44 & $2^{\text {nd }}$ \\
Food Poisoning & $16(13.3)$ & $24(20.0)$ & $7(5.8)$ & $15(12.5)$ & $58(58.3)$ & 2.38 & $6^{\text {th }}$ \\
Flowering rate & $27(22.5)$ & $13(10.08)$ & $31(25.8)$ & $19(15.8)$ & $30(25.0)$ & 3.08 & $5^{\text {th }}$ \\
Shelf life & $70(58.3)$ & $25(20.8)$ & $15(12.5)$ & $6(5.0)$ & $4(3.3)$ & 4.26 & $1^{\text {st }}$ \\
Pollution & $6(5.0)$ & $4(3.3)$ & $17(14.2)$ & $17(14.2)$ & $76(63.3)$ & 1.73 & $7^{\text {th }}$ \\
Profitability & $23(19.2)$ & $45(37.5)$ & $11(9.2)$ & $15(12.5)$ & $26(21.7)$ & 3.20 & $4^{\text {th }}$ \\
Ecosystem imbalance & $0(0.0)$ & $0(0.0)$ & $10(8.3)$ & $17(14.2)$ & $93(77.5)$ & 1.31 & $9^{\text {th }}$ \\
\hline
\end{tabular}

Source: Field Survey 2016. Note: Figures in parenthesis are percentage

SA - strongly agree, A - agree, I - indifference, D - disagree, SD - strongly disagree

Table 5: Constraints faced by farmers using chemical and biological pest control methods

\begin{tabular}{lccccccc}
\hline & Very severe & Severe & Moderately severe & Less severe & Not severe & Mean & Rank \\
\hline Inadequate knowledge & $10(8.3)$ & $11(9.2)$ & $12(10.0)$ & $26(21.7)$ & $42(35.0)$ & 2.22 & $4^{\text {th }}$ \\
High Cost & $43(35.8)$ & $18(15.0)$ & $10(8.3)$ & $10(8.3)$ & $20(16.7)$ & 3.53 & $1^{\text {st }}$ \\
Adverse effect on yield & $7(5.8)$ & $1(0.8)$ & $6(5.0)$ & $19(15.8)$ & $68(56.7)$ & 1.61 & $7^{\text {th }}$ \\
Adverse effect on soil fertility & $9(7.5)$ & $8(6.7)$ & $12(10.0)$ & $17(14.2)$ & $55(45.8)$ & 2.00 & $6^{\text {th }}$ \\
Health Challenge & $14(11.7)$ & $10(8.3)$ & $12(10.0)$ & $18(15.0)$ & $47(39.2)$ & 2.27 & $3^{\text {rd }}$ \\
Inadequate access & $11(9.2)$ & $12(10.0)$ & $11(9.2)$ & $16(13.3)$ & $51(42.5)$ & 2.17 & $5^{\text {th }}$ \\
Long distance to point of purchase & $18(15.0)$ & $7(5.8)$ & $10(8.3)$ & $17(14.2)$ & $49(40.8)$ & 2.28 & $2^{\text {nd }}$ \\
\hline
\end{tabular}

Source: Field Survey 2016

Table 6: Relationship between socio-economic characteristics and the effect of pest control methods

\begin{tabular}{lcccc}
\hline $\begin{array}{l}\text { Socio economic } \\
\text { variable }\end{array}$ & $\mathrm{N}$ & $\mathrm{R}$ & $\begin{array}{c}\mathrm{p} \\
\text { value }\end{array}$ & Decision \\
\hline Age & 120 & $-0.271^{* *}$ & 0.003 & Significant \\
Educational level & 120 & $0.268^{* *}$ & 0.003 & Significant \\
Household size & 120 & $-0.209^{*}$ & 0.022 & Significant \\
Years of faming & 120 & $-0.225^{*}$ & 0.013 & Significant \\
experience & 120 & $0.190^{*}$ & 0.038 & Significant \\
Farm Size & 120
\end{tabular}

**Correlation is significant at the 0.01 level (2-tailed),

*Correlation is significant at the 0.05 level (2-tailed)

increases, farmers tend to have a contrary perception about chemical and biological pest control method which might be due to their experiences over time. The perceived effect of chemical and biological pest control methods also reduces as household size increases most likely because these chemicals are not subsidized for the farmers by any government agency and the amount of money available to a farming household will determine how much will be spent on agrochemical, knowing fully well that the larger the household size, the higher the amount of money that will be required for upkeep. However, there is a significant positive correlation coefficient between the perceived effect of pest control methods and educational level as well as farm size (0.268, 0.190; $\mathrm{p}<0.05)$, respectively. This shows that education could play an important role in improving the farmer's perception about the effect of chemical and biological pest control methods. Hence, education positively influences the farmers' perceptions about chemical and biological pest control methods. Also, a large farm requires more effort in pest control which is much easier with the use of chemicals and biological pest control methods, thus, farm size could also positively influence farmers' perception. However, this result was contrary to the earlier reports of Oladele $e t$ al. (2014) that age group had no significant effect on awareness of pest control on vegetables and farmers education status have no impact on knowledge of insect pest control method.

\section{CONCLUSION/RECOMMENDATIONS}

Based on the findings of this study, it can be concluded that majority of the farmers were aware of the information about chemical methods of pest control much more than biological pest control method. Pest management practices commonly used by the farmers are cultural and chemical control methods. This shows that the idea of integrating cultural pest control methods with both chemical and biological methods of pest control was not a new thing among rural farmers. It was also found that high cost was the only severe constraint faced by farmers in using both chemical 
and biological pest control methods. Finally, chemical and biological pest control methods have been perceived by farmers to have economic benefits rather than the effect on food poisoning and other environmental cost. In lieu of these, the following recommendations were made:

- There is the need for government to make agrochemicals (pesticides) available to the farmers at a subsidized rate so that a larger percentage of the farmers will be able to use it to control pest in an optimal level on their farms given its economic benefits.

- Extension agents should educate, sensitize and enlighten the farmers to stimulate the adoption of biological pest control method and the need to integrated pest control management given its lesser environmental implication cost.

- There should be advocacy on the appropriate use of these chemicals and the environmental and health implication of chemical pest control method should be the focus of government, extension agents and other relevant agencies on media.

\section{REFERENCES}

Abunyewah G.K., Afreh-Nuamah K., Nboyine J.A., Obeng-Ofori D. and Billah M.K. (2015) Farmers' perception of a biological control agent, Oecophyllalonginoda Latreille (Hymenoptera: Formicidae) and its effects on the quality of citrus fruits in Ghana. African Journal of Agric. Res., 10 (51), 4646-4652 DOI: 10.5897/AJAR2015.9958

Agbaje M.A., Okunmadewa F.Y., Omomona B.T. and Oni O.A. (2013). An assessment of vulnerability to poverty in rural Nigeria. ARPN Journal of Agriculture and Biological Science, 8 (1): 60-75

Aktar M.D.W., Sengupta D. and Chowdhury A. (2009). Impact of pesticides use in agriculture: their benefits and hazards. Interdiscip Toxicol., 2 (1): 1-12

Bale J.S., van Lenteren J.C. and Bigler F. (2008) Biological control and sustainable food production. Philos Trans R SocLond B Biol Sci., 363 (1492): 761-776

Bolarinwa K.K. and Oyeyinka R.A. (2011). Use of cell phone by farmers and its implication on farmers' production capacity in Oyo State, Nigeria. World Academy of Science, Engineering and Technology, 51, 653-658

Bretveld R.W., Thomas C.M.G., Scheepers P.T.J., Zielhuis G.A. and Roeleveld N. (2006). Pesticide exposure: the hormonal function of the reproductive system disrupted? Eprod Biol Endocrinol. 4:30. Published online 2006 May 31. DOI: 10.1186/14777827-4-30 PMCID:PMC1524969

Bueno A.F., Batistela M.J., Oliveira de Freitas Bueno R.C., Franca-Neto J.B., Nishikawa M.A.N. and Filho A.L. (2011). Effects of integrated pest management, biological control and prophylactic use of insecticides on the management and sustainability of soybean. Crop Protection 30, 937-945

Chamber H.W., Boone Z.S., Carr R.L. and Chanbers J.E. (2001). Chemistry of organophosphorus insecticides. In: Robert I.K. (ed.) Handbook of Pesticides Toxicology, Academics Press, CA, pp. 913-917
Charles O. (2014). Access to inputs for smallholders in Africa: A paper presented by President UNFFE in Rome, Italy.

http://www.fertilizer.org/en/doc_library/Knowledge\%20R esources.pdf

Damalas C.A. and Eleftherohorinos I.G. (2011) Pesticide Exposure, Safety Issues, and Risk Assessment Indicators. Int. Jour. Environ. Res. \& Public Health, 8, 1402-1419. http://dx.doi.org/10.3390/ijerph8051402

FAO. (2005). FAOSTAT Database, http://apps.fao.org/, Food and Agricultural Organization. Accessed on 11.03.2017

Gerald W., Biing-Hwan L. and Utpal V. (1995), Restricting pesticide use: the impact on profitability by farm size. J. Agr. \& Applied Econ. 27 (2): 352-362

Idehen and Oshodin O.G. (2007). Insights into Benin traditional methods of disease prevention. The Journal of Pan African Studies, 1 (8): 114-119

Ngowi A.V.F, Mbise T.J, Ijani A.S.M., London L. and AJayi O.C. (2007) Crop Protection, 26: 1617-1624

Obilor S.I. (2012). The Impact of commercial banks' credit to agriculture on agricultural development in Nigeria: An Econometric Analysis: Int. Jour. of Business, Humanities and Technology 3 (1)

Oladele A.O., Babarinde S.A., Odewole A.F., Aremu P.A. and Popoola K. (2014). Rural farmers' perceptions, knowledge and management of insect pests of fruit vegetables in Ogbomoso Agricultural Zone of Nigeria. International Letters of Natural Sciences, 25: 18-28. DOI: $10.18052 / w w w . s c i p r e s s . c o m / I L N S .25 .18$

Oladele O.I. (2006) Multilinguality of farm broadcast and agriculture information access in Nigeria. Nordic Journal of African Studies, 15 (2): 199-205

Ooi P.A.C. and Kenmore P.E. (2005). Impact of educating farmers about biological control in farmer field schools. Proc. Int. Symp. On Biological Control of Arthropods, 12-16 Sept. 2005, Davos, Switzerland. USDA Forest Service, Forest Health Technology Enterprise Team-2005-08: 277-289

Parveen S. and Nakagoshi N. (2001). An analysis of pesticides use for rice pest management in Bangladesh. Journal of International Development and Cooperation, 8 (1), 107-126

Peng R.G.C. (2003). Marriage and family in the contemporary rural areas of Shaanxi: traditions, customs, and their changes.

http://www.usccb.net/conference/conference20/Fam ilyShaanxiGao.pdf (assessed on 4th July, 2014)

Selvarajah A. and Thiruchelvam S. (2007). Factors affecting pesticide use by farmers in Vavuniya District. Jour. of Tropical Agric. Res. 19:380-388

Sexton S.E., Lei Z., and Zilberman D. (2007). The economics of pesticides and pest control. Int. Rev. Environ. Resource Econ. 1, 271-326

SP-IPM. (2006). Biological alternatives to harmful chemical pesticides. IPM Research Brief No. 4. SPIPM Secretariat, International Institute of Tropical Agriculture (IITA) Cotonou, Benin

Tinyami E.T., Wook C.J., Shendeh T.T., Eko E.A. and Afoh C.O. (2014) Small-scale tomato cultivators' perception on pesticides usage and practices in Buea Cameroon. Health Sci. Res., 6, 2945-2958. http://dx.doi.org/10.4236/health.2014.621333

Van Lenteren J.C. (2005). Early entomology and discovery of insect parasitoids. Biological Control 32: $2-7$ 